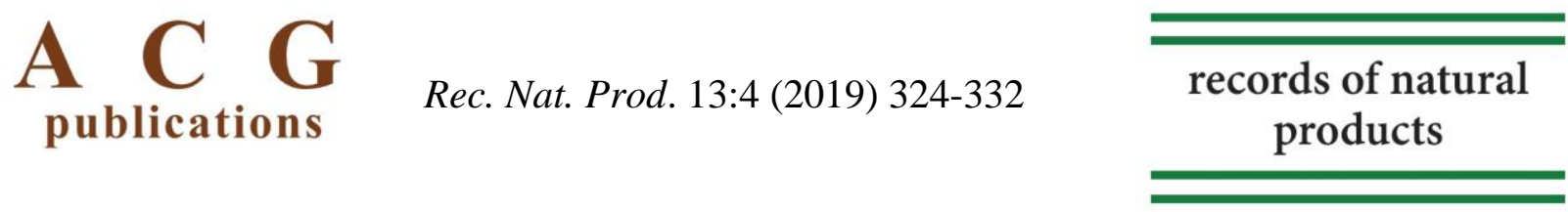

\title{
Chemical Compositions of Essential Oil of Piper Species from Atlantic Forest of Amazonia, Brazil
}

\author{
Carolina A. de Araujo 1 , Claudio A.G. da Camara ${ }^{1 *}$, \\ Marcilio M. de Moraes@1, Geraldo José Nascimento de Vasconcelos?2, \\ Marta R. Pereira ${ }^{3}$ and Charles E. Zartman ${ }^{3}$
}

\author{
${ }^{1}$ Department of Chemistry, Rural Federal University of Pernambuco, Street Dom Manoel de \\ Medeiros s/n, 52.171-030 Recife, PE, Brazil \\ ${ }^{2}$ Federal University of Amazonas - Campus ICET. Street Nossa Senhora do Rosário, 3863, \\ Tiradentes - CEP: 69103-128, Itacoatiara, Amazonas, Brazil \\ ${ }^{3}$ National Institute for Amazonian Research, Department of Biodiversity \\ Av. André Araújo, 2936, Petrópolis, CEP 69060-001, Manaus, Amazonas, Brazil
}

(Received September 13, 2018; Revised November 06, 2018; Accepted November 07, 2018)

\begin{abstract}
Essential oils from the leaves of Piper japurense (Miq.) C. DC., P. coariense Yunk., P. auriculifolium Yunk., P. curtistilum C.DC., P. alatipetiolatum Yunk. and P. brevesanum Yunk. from the Amazon Forest (Brazil) were obtained through hydrodistillation. The chemical composition of the oils was determined using gas chromatography and mass spectrometry, which revealed the presence of 108 compounds representing 95.14\%, $95.64 \%, 95.57 \%, 92.05 \%, 96.24 \%$ and $91.316 \%$ of the oils, respectively. All oils had an abundance of sesquiterpenes, except the oil from $P$. alatipetiolatum, which had a higher percentage of monoterpenes. The major components were $\alpha$-eudesmol in the $P$. japurense $(22.05 \%)$ and $P$. coariense $(27.33 \%)$ oils, premnaspirodiene $(32.26 \%)$ in the $P$. auriculifolium oil, caryophyllene oxide $(28.69 \%)$ in the $P$. curtistilum oil, linalool (43.88\%) in the P. alatipetiolatum oil and $\beta$-elemene $(12.75 \%)$ in the P. brevesanum oil. Although the oils were composed of terpenes, the chemical analysis revealed qualitative and quantitative differences. This is the first report of the chemical composition of these six species of Piper that occur in the Amazonia biome in Brazil.
\end{abstract}

Keywords: Piper spp; essential oil; $\alpha$-eudesmol; premnaspirodiene; caryophyllene oxide; linalool. @ 2019 ACG Publications. All rights reserved.

\section{Introduction}

The family Piperacea is considered one of the most basal clades among angiosperms [1]. There are approximately 290 species of this family distributed throughout Brazil, with a greater concentration in equatorial northern region of the county. One hundred thirty-seven species have been recorded for the state of Amazonas [2], which is located in the center of the Amazon Forest. The leaves of many species of the genus Piper are used in the form of infusions as folk remedies for the treatment of fever and inflammation [3].

The investigation of the biological properties of essential oils from plants of this genus has reveled antimicrobial [4], antioxidant [5], acaricidal [6] and insecticidal [7] activities. These oils are

\footnotetext{
*Corresponding author: E-Mail: claudio_agc@hotmail.com ; Phone:086-592-2184180 Fax:086-592-2181722
} 
basically composed of phenylpropanoids, such as safrole, dillapiole and myristicin, or terpenes, such as limonene, $\beta$-caryophyllene, spathulenol, $(E)$-nerolidol, bicyclogermacrene and $\alpha$-cadinol [8].

The species Piper japurense (Miq.) C. DC., P. coariense Yunk., P. auriculifolium Yunk., $P$. curtistilum C.DC., P. alatipetiolatum Yunk. and P. brevesanum Yunk. occur in the state of Amazonas, Brazil. Due to the shape of their inflorescences, these plants are known locally as "long pepper" or "monkey pepper". The six species selected for the present study are bushes with considerable morphological similarity. As part of a larger investigation of the aromatic flora of the Amazonia biome, this paper offers the first description and comparation study of the chemical composition of essential oils from the leaves of $P$. japurense, $P$. coariense, $P$. auriculifolium, $P$. curtistilum, $P$. alatipetiolatum and P. brevesanum that occur in the state of Amazonas, Brazil.

\section{Materials and Methods}

\subsection{Collection of Plant Material}

The fresh leaves of $P$. japurense (Miq.) C. DC. (S 04 05' 26"; W $\left.63^{\circ} 18^{\prime} 51^{\prime \prime}\right)$, P. coariense

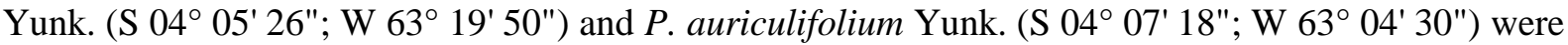
collected in Coari, in the interior of the state of Amazonas. P. curtistilum C.DC. (S 03 46' 32"; W 60 $\left.18^{\prime} 22^{\prime \prime}\right)$ were collected in Careiro da Várzea, metropolitan region of the state of Amazonas. $P$. alatipetiolatum Yunk (S 02 39' 04"; W 60'02' 29") and P. brevesanum Yunk. (S 02 39' 04"; W 60 $\left.02^{\prime} 29^{\prime \prime}\right)$ were collected in Manaus, capital of the state of Amazonas. The plants were identified by botanist Pereira M.R. (National Institute for Amazonian Research). Voucher of both samples were mounted and deposited in the Herbário do Instituto Nacional de Pesquisas da Amazônia (INPA), under numbers: (681) P. japurense, (682) P. coariense, (684) P. auriculifolium, (698) P. curtistilum, (701) $P$. alatipetiolatum and (703) $P$. brevesanum.

\subsection{Chemicals}

All monoterpenes ( $\alpha$-pinene, limonene, linalool e $\alpha$-terpineol), sesquiterpenes ( $\alpha$-copaene, $\beta$ caryophyllene, aromadendrene, $\alpha$-humulene, allo-aromadendrene, bicyclogermarcrene, $(E)$-nerolidol and caryophyllene oxide were purchased from Sigma-Aldrich - Brazil.

\subsection{Essential Oils Extraction and GC-FID Analysis}

The essential oils from fresh leaves (100 g) were separately isolated using a modified Clevenger-type apparatus and hydrodistillation for $2 \mathrm{~h}$. The oil layers were separated and dried over anhydrous sodium sulfate, stored in hermetically sealed glass containers, and kept at low temperature $\left(-5^{\circ} \mathrm{C}\right)$ until analysis. Total oil yields were expressed as percentages $(\mathrm{g} / 100 \mathrm{~g}$ of fresh plant material). All experiments were carried out in triplicate. Quantitative GC analysis were carried out using a PerkinElmer Clarus 500 GC apparatus equipped with a flame ionization detector (FID) and a nonpolar DB-5 fused silica capillary column $(30 \mathrm{~m} \times 0.25 \mathrm{~mm} \times 0.25 \mu \mathrm{m})(\mathrm{J} \& \mathrm{~W}$ Scientific). The oven temperature was programmed from 60 to $240^{\circ} \mathrm{C}$ at a rate $3{ }^{\circ} \mathrm{C} \mathrm{min}{ }^{-1}$. Injector and detector temperatures were $260^{\circ} \mathrm{C}$. Hydrogen was used as the carrier gas at a flow rate of $1 \mathrm{~mL} \mathrm{~min}^{-1}$ in split mode $(1: 30)$. The injection volume was $0.5 \mu \mathrm{L}$ of diluted solution (1/100) of oil in $n$-hexane. The amount of each compound was calculated from GC-FID peak areas in the order of DB-5 column elution and expressed as a relative percentage of the total area of the chromatograms. Analyses were carried out in triplicate.

\subsection{GC-MS Analysis}

The qualitative Gas Chromatography-Mass Spectrometry (GC-MS) analysis were carried out using a Varian 220-MS IT GC system with a mass selective detector, mass spectrometer in EI $70 \mathrm{eV}$ with a scan interval of $0.5 \mathrm{~s}$ and fragments from 40 to $550 \mathrm{Da}$. fitted with the same column and temperature program as that for the GC-FID experiments, with the following parameters: carrier gas = helium; flow rate $=1 \mathrm{~mL} \mathrm{~min}^{-1}$; split mode (1:30); injected volume $=1 \mu \mathrm{L}$ of diluted solution $(1 / 100)$ of oil in $n$-hexane. 


\subsection{Identification of Components}

Identification of the components was based on GC-MS retention indices with reference to a homologous series of C8-C40 n-alkanes calculated using the Van der Dool and Kratz equation [9] and by computer matching against the mass spectral library of the GC-MS data system (NIST and WILEY 11th) and co-injection with authentic standards as well as other published mass spectra [10-12]. Area percentages were obtained from the GC-FID response without the use of an internal standard or correction factors.

\section{Results and Discussion}

Hydrodistillation of the leaves of the six species of Piper furnished yellowish oils with citric aromas. The highest yield was obtained with $P$. auriculifolium $(0.25 \%)$, followed by $P$. coariense $(0.10 \%), P$. alatipetiolatum $(0.10 \%), P$. japurense $(0.05 \%), P$. brevesanum $(0.05 \%)$ and $P$. curtistilum $(0.03 \%)$ (Table 1). These results are in agreement with data described for other species of Piper. Santana et al., (2016) report a $0.2 \%$ yield for $P$. longispicum, which is close to the yield found for $P$. auriculifolium [13]. Rameshkumar et al., (2011) found the same yield for the leaf oil from $P$. longum as that obtained for P. japurense and P. brevesanum [14] (Table 1). Andrade and Zoghbi (2007) report the same yield for the leaf oil from P. glandulosissimum (0.03\%) as that found for P. curtistilum [15]. Besides the genetic variability of each species investigated, biotic and abiotic factors can also affect the yield of essential oils [16].

Table 1. Percentage composition, yield of essential oils from leaves of Piper species.

\begin{tabular}{|c|c|c|c|c|c|c|c|c|c|}
\hline \multirow{2}{*}{ Compounds } & \multirow{3}{*}{$\mathbf{R} \mathbf{I}^{\mathbf{a}}$} & \multirow{3}{*}{$\mathbf{R I}^{\mathbf{b}}$} & Pja & Pco & Pau & Pcu & Pal & Pbr & \multirow{3}{*}{ MI } \\
\hline & & & \multicolumn{6}{|c|}{$\left(\% \pm \mathrm{SD}^{\mathrm{a}}\right)$} & \\
\hline Yield (w/w) & & & 0.05 & 0.10 & 0.25 & 0.03 & 0.10 & 0.05 & \\
\hline$\alpha$-Pinene & 932 & 935 & - & - & - & - & 2.56 & - & RI, MS, CI \\
\hline Limonene & 1024 & 1022 & - & - & - & 0.61 & 1.88 & - & RI, MS, CI \\
\hline Sylvestrene & 1025 & 1028 & - & - & - & - & - & 0.29 & RI, MS \\
\hline Benzene acetaldehyde & 1036 & 1040 & - & - & 0.48 & - & - & - & RI, MS \\
\hline Linalool & 1095 & 1100 & 0.36 & - & - & 0.72 & 43.88 & - & RI, MS, CI \\
\hline Phenyl ethyl alcohol & 1106 & 1110 & - & - & 0.64 & - & - & - & RI, MS \\
\hline Coahuilensol & 1166 & 1165 & - & - & 5.00 & - & - & - & RI, MS \\
\hline$\alpha$-Terpineol & 1186 & 1190 & 0.24 & - & - & - & 2.23 & - & RI, MS, CI \\
\hline$\delta$-Elemene & 1335 & 1335 & - & - & - & 0.70 & - & 0.38 & RI, MS \\
\hline$\alpha$-Cubebene & 1345 & 1350 & - & - & 4.10 & 0.99 & - & 0.34 & RI, MS \\
\hline$\alpha$-Ylangene & 1373 & 1374 & 0.80 & - & - & 1.47 & - & - & RI, MS \\
\hline$\alpha$-Copaene & 1374 & 1375 & - & 0.74 & - & 2.57 & 0.90 & 5.71 & RI, MS, CI \\
\hline Isoledene & 1374 & 1378 & - & - & 1.04 & - & - & - & RI, MS \\
\hline$\beta$-Bourbonene & 1387 & 1382 & - & - & & 0.70 & - & - & RI, MS \\
\hline$\beta$-Elemene & 1389 & 1388 & 0.73 & - & 0.89 & 4.71 & - & 12.75 & RI, MS \\
\hline Longifolene & 1407 & 1405 & 0.25 & - & - & - & - & - & RI, MS \\
\hline$\alpha$-Gurjunene & 1409 & 1405 & - & 0.43 & - & - & - & - & RI, MS \\
\hline$\beta$-Caryophyllene & 1417 & 1412 & 5.71 & 10.30 & - & 2.55 & 16.11 & 7.26 & RI, MS, CI \\
\hline$\beta$-Copaene & 1430 & 1428 & 1.11 & 0.51 & 0.43 & 1.61 & - & 0.47 & RI, MS \\
\hline$\beta$-Gurjunene & 1431 & 1429 & - & - & 0.44 & - & - & - & RI, MS \\
\hline$\alpha$-trans-Bergamotene & 1432 & 1433 & - & - & 0.37 & - & - & - & RI, MS \\
\hline Aromadendrene & 1439 & 1436 & - & 0.38 & - & - & - & - & RI, MS, CI \\
\hline$\alpha$-Himachalene & 1449 & 1452 & - & - & 0.93 & - & - & - & RI, MS \\
\hline$\alpha$-Humulene & 1452 & 1453 & 0.78 & 0.98 & - & - & 2.99 & 1.86 & RI, MS, CI \\
\hline allo-Aromadendrene & 1458 & 1457 & - & 0.48 & - & - & - & 0.72 & RI, MS, CI \\
\hline $\begin{array}{l}\text { cis-Muurola-4(14),5- } \\
\text { diene }\end{array}$ & 1465 & 1470 & 2.17 & - & - & - & - & - & RI, MS \\
\hline $\begin{array}{l}\text { 4,5-di-epi- } \\
\text { Aristolochene }\end{array}$ & 1471 & 1472 & - & - & 0.41 & - & - & - & RI, MS \\
\hline
\end{tabular}




\begin{tabular}{|c|c|c|c|c|c|c|c|c|c|}
\hline Table 1 Continued.. & $\mathbf{R I}^{\mathbf{a}}$ & $\mathbf{R I}^{\mathbf{b}}$ & Pja & Pco & Pau & Pcu & Pal & Pbr & MI \\
\hline$\gamma$-Gurjunene & & & - & 0.76 & - & - & - & - & RI, MS \\
\hline$\beta$-Chamigrene & 1476 & 1477 & - & - & - & - & 0.49 & 1.08 & RI, MS \\
\hline$\gamma$-Muurolene & 1478 & 1478 & 1.86 & - & 3.91 & 6.30 & 0.95 & 0.50 & RI, MS \\
\hline Widdra-2,4(14)-diene & 1481 & 1484 & 1.86 & - & - & - & - & - & RI, MS \\
\hline Germacrene D & 1484 & 1488 & 0.38 & - & - & - & 5.79 & 7.05 & RI, MS \\
\hline$\beta$-Selimene & 1489 & 1489 & - & - & - & 1.74 & 2.62 & 3.19 & RI, MS \\
\hline cis- $\beta$-Guaiene & 1492 & 1490 & - & 0.57 & - & - & - & - & RI, MS \\
\hline epi-Cubebol & 1493 & 1491 & - & - & - & 2.44 & - & - & RI, MS \\
\hline Viridiflorene & 1496 & 1492 & - & 1.22 & - & - & 3.40 & - & RI, MS \\
\hline Valencene & 1496 & 1494 & - & - & - & - & - & 6.23 & RI, MS \\
\hline Curzerene & 1499 & 1496 & 3.81 & - & - & - & - & - & RI, MS \\
\hline $\begin{array}{l}\text { 4-epi-cis- } \\
\text { Dihydroagarofuran }\end{array}$ & 1499 & 1496 & - & 4.26 & - & - & - & - & RI, MS \\
\hline Bicyclogermacrene & 1500 & 1498 & 1.38 & - & - & - & - & 11.61 & RI, MS, CI \\
\hline$\alpha$-Muurolene & 1500 & 1500 & 1.12 & - & - & 1.81 & - & - & RI, MS \\
\hline$\beta$-Dihydro agarofuran & 1503 & 1502 & 3.81 & 15.35 & - & - & - & - & RI, MS \\
\hline$(E, E)-\alpha$-Farnesene & 1505 & 1504 & 0.30 & - & - & - & - & - & RI, MS \\
\hline Premnaspirodiene & 1505 & 1502 & - & - & 32.26 & - & - & - & RI, MS \\
\hline$\alpha$-Bulnesene & 1509 & 1507 & - & - & 10.01 & - & - & - & RI, MS \\
\hline$\delta$-Amorphene & 1511 & 1511 & - & 0.41 & - & - & - & - & RI, MS \\
\hline$\gamma$-Cadinene & 1513 & 1512 & 5.83 & 1.23 & - & 3.15 & 0.59 & 8.25 & RI, MS \\
\hline Cubebol & 1514 & 1513 & - & - & - & 1.62 & - & - & RI, MS \\
\hline trans-Calamenene & 1521 & 1515 & 0.88 & 0.41 & - & 3.19 & - & - & RI, MS \\
\hline$\beta$-Sesquiphellandiene & 1521 & 1517 & - & - & 0.39 & - & - & - & RI, MS \\
\hline$\delta$-Cadinene & 1522 & 1520 & - & - & 0.62 & - & - & - & RI, MS \\
\hline cis-Calamenene & 1528 & 1525 & - & - & 2.70 & - & - & - & RI, MS \\
\hline$\alpha$-Cadinene & 1537 & 1534 & 0.67 & - & - & 1.98 & - & - & RI, MS \\
\hline$\alpha$-Calacorene & 1544 & 1541 & 0.80 & - & 0.63 & - & - & - & RI, MS \\
\hline Hedycaryol & 1546 & 1546 & 1.71 & 0.68 & - & - & - & 0.35 & RI, MS \\
\hline Germacrene B & 1559 & 1555 & 3.26 & 0.33 & - & - & - & 2.81 & RI, MS \\
\hline (E)-Nerolidol & 1561 & 1560 & 0.65 & - & 2.98 & 0.60 & 2.71 & 1.07 & RI, MS, CI \\
\hline Palustrol & 1567 & 1567 & - & 0.44 & - & - & - & - & RI, MS \\
\hline $\begin{array}{l}1 \alpha, 10 \alpha \text {-epoxy } \\
\text { Amorph-4-ene }\end{array}$ & 1570 & 1570 & - & - & 0.36 & - & - & - & RI, MS \\
\hline Caryolan-8-ol & 1571 & 1572 & - & - & - & 0.63 & - & - & RI, MS \\
\hline Spathulenol & 1577 & 1573 & 0.91 & 0.36 & - & - & 0.64 & 1.21 & $\mathrm{RI}, \mathrm{MS}$ \\
\hline Caryophyllene oxide & 1582 & 1578 & 2.24 & 2.52 & 1.41 & 28.69 & 2.73 & 1.07 & RI, MS, CI \\
\hline Gleenol & 1586 & 1587 & - & - & 0.53 & - & - & - & $\mathrm{RI}, \mathrm{MS}$ \\
\hline$\beta$-Copaen-4- $\alpha$-ol & 1590 & 1590 & - & - & 0.40 & - & - & - & RI, MS \\
\hline Viridiflorol & 1592 & 1593 & 1.07 & - & - & - & - & - & RI, MS \\
\hline $\begin{array}{l}\text { Salvial-4(14)-em-1- } \\
\text { one }\end{array}$ & 1594 & 1594 & 0.24 & - & - & - & - & - & RI, MS \\
\hline Carotol & 1594 & 1594 & 0.73 & - & - & - & - & - & RI, MS \\
\hline Cubeban-11-ol & 1595 & 1597 & 0.58 & 0.67 & - & - & - & - & RI, MS \\
\hline Widdrol & 1599 & 1603 & - & - & 0.73 & - & - & - & RI, MS \\
\hline Rosifoliol & 1600 & 1603 & 0.98 & 0.89 & - & - & - & - & $\mathrm{RI}, \mathrm{MS}$ \\
\hline Guaiol & 1600 & 1603 & - & 1.22 & - & 0.60 & - & - & RI, MS \\
\hline Humelene epoxide II & 1608 & 1606 & - & - & - & 2.22 & - & - & RI, MS \\
\hline$\beta$-Athantol & 1608 & 1613 & - & - & - & - & - & 2.09 & RI, MS \\
\hline 1,10-di-epi-Cubenol & 1618 & 1616 & 1.36 & - & - & 0.69 & - & - & RI, MS \\
\hline Junenol & 1618 & 1620 & - & - & - & 0.61 & - & - & RI, MS \\
\hline 10-epi- $\gamma$-Eudesmol & 1622 & 1623 & 6.01 & 13.32 & 1.12 & - & - & - & RI, MS \\
\hline 1-epi-Cubenol & 1627 & 1625 & 1.72 & - & 1.79 & 3.27 & - & - & RI, MS \\
\hline Eremoligenol & 1629 & 1627 & 0.63 & 1.55 & - & - & - & - & RI, MS \\
\hline$\gamma$-Eudesmol & 1630 & 1630 & 3.67 & 2.43 & - & 0.73 & - & - & RI, MS \\
\hline Hinesol & 1640 & 1637 & 0.39 & 0.49 & - & - & - & - & RI, MS \\
\hline epi- $\alpha$-Muurolol & 1640 & 1632 & - & - & 0.90 & 2.22 & - & 1.40 & $\mathrm{RI}, \mathrm{MS}$ \\
\hline
\end{tabular}




\begin{tabular}{|c|c|c|c|c|c|c|c|c|c|}
\hline Table 1 Continued.. & $\mathbf{R} \mathbf{I}^{\mathbf{a}}$ & $\mathbf{R I}^{\mathbf{b}}$ & Pja & Pco & Pau & Pcu & Pal & Pbr & MI \\
\hline$\alpha$-Muurolol & 1644 & 1640 & 4.33 & 0.35 & 0.91 & 1.09 & - & - & RI, MS \\
\hline Cubenol & 1645 & 1645 & 2.23 & - & - & - & - & - & RI, MS \\
\hline Agarospirol & 1646 & 1646 & - & 1.74 & - & - & - & - & RI, MS \\
\hline$\beta$-Eudesmol & 1649 & 1652 & - & - & 2.94 & - & - & - & RI, MS \\
\hline Pogostol & 1651 & 1655 & - & - & - & - & - & 6.59 & RI, MS \\
\hline$\alpha$-Eudesmol & 1652 & 1656 & 22.05 & 27.33 & - & - & - & - & RI, MS \\
\hline$\alpha$-Cadinol & 1652 & 1646 & - & - & 0.69 & 5.77 & 2.40 & - & RI, MS \\
\hline Valerianol & 1656 & 1657 & - & - & 0.49 & - & - & - & RI, MS \\
\hline Selin-11-en-4- $\alpha$-ol & 1658 & 1658 & 1.82 & - & - & - & 1.38 & 2.46 & RI, MS \\
\hline neo-Intermedeol & 1658 & 1662 & - & - & 0.98 & - & - & - & RI, MS \\
\hline Allo-himachalol & 1661 & 1660 & - & - & 2.36 & - & - & - & RI, MS \\
\hline 7-epi- $\alpha$-Eudesmol & 1662 & 1661 & 0.57 & 1.13 & - & - & - & - & RI, MS \\
\hline Intermedeol & 1665 & 1664 & - & - & - & - & - & 1.17 & RI, MS \\
\hline $\begin{array}{l}\text { trans-Calamenen-10- } \\
\text { ol }\end{array}$ & 1668 & 1667 & 0.29 & - & 0.71 & 0.89 & - & - & RI, MS \\
\hline $\begin{array}{l}\text { 14-hydroxy-9-epi- }(E)- \\
\text { Caryophyllene }\end{array}$ & 1668 & 1669 & - & 0.59 & - & - & - & - & RI, MS \\
\hline epi-Zizanone & 1668 & 1670 & 0.37 & - & - & - & - & - & RI, MS \\
\hline $\begin{array}{l}\text { 8-hydroxy-Isobornyl } \\
\text { isobutanoate }\end{array}$ & 1674 & 1671 & 2.48 & 0.40 & - & - & - & - & RI, MS \\
\hline Cadalene & 1675 & 1676 & - & - & - & 3.22 & - & - & RI, MS \\
\hline Helifolenol C & 1681 & 1679 & - & - & 2.49 & - & - & - & RI, MS \\
\hline 8-Cedren-13-ol & 1688 & 1685 & - & - & 1.24 & - & - & - & RI, MS \\
\hline $\begin{array}{l}\text { Eudesmol-7(11)-en-4- } \\
\text { ol }\end{array}$ & 1700 & 1694 & - & 0.41 & - & - & - & - & RI, MS \\
\hline Mayurone & 1709 & 1711 & - & - & 0.43 & - & - & - & RI, MS \\
\hline Isobicyclogermacrenal & 1733 & 1726 & - & - & 0.48 & - & - & - & RI, MS \\
\hline $\begin{array}{l}\text { 7,14-anydro- } \\
\text { Amorpha-4,9-diene }\end{array}$ & 1755 & 1749 & - & - & 2.01 & - & - & - & RI, MS \\
\hline $\begin{array}{l}\text { Benzyl benzoate } \\
2-\alpha \text {-hydroxy- }\end{array}$ & 1759 & 1761 & - & 0.76 & - & - & - & - & $\begin{array}{l}\text { RI, MS } \\
\text { RI, MS }\end{array}$ \\
\hline $\begin{array}{l}\text { Amorpha-4,7(11)- } \\
\text { diene }\end{array}$ & 1775 & 1771 & - & - & - & 1.96 & - & - & \\
\hline$(3 E)$-Cembrene A & 1947 & 1951 & - & - & - & - & - & 3.40 & RI, MS \\
\hline $\begin{array}{l}\text { (6E,10Z)-Pseudo } \\
\text { phytol }\end{array}$ & 2018 & 2025 & - & - & 0.90 & - & - & - & RI, MS \\
\hline Total & & & 95.14 & 95.64 & 95.57 & 92.05 & 96.24 & 91.31 & \\
\hline Monoterpenes & & & 0.60 & - & 6.12 & 1.33 & 50.55 & 0.29 & \\
\hline Sesquiterpenes & & & 94.54 & 95.64 & 89.45 & 90.72 & 45.69 & 91.02 & \\
\hline
\end{tabular}

$\mathrm{RI}^{\mathrm{a}}=$ Retention indices from the literature $[10,11,12] . \mathrm{RI}^{\mathrm{b}}=$ Retention indices calculated from retention times in relation to those of a series $\mathrm{C}_{8}-\mathrm{C}_{40}$ of n-alkanes on a 30m DB-5 capillary column. Pja $=P$. japurense, $\mathrm{Pco}=P$. coariense, Pau $=P$. auriculifolium, $\mathrm{Pcu}=P$. curtistilum, $\mathrm{Pal}=P$. alatipetiolatum and $\mathrm{Pbr}=P$. brevesanum. ${ }^{\mathbf{a}}$ Standard deviation were insignificant and were excluded from the Table except where stated. RI = retention index; MS = mass spectroscopy; CI: Co-injection with authentic compounds.

Species of Piper are known for the production of essential oils, which are responsible for different biological properties. These properties can be attributed to wide varieties of metabolites belonging to the chemical classes of monoterpenes, sesquiterpenes and phenylpropanoids (17). The following major constituents stood out in the Piper oils investigated in the present study: linalool, caryophyllene oxide, $\alpha$-eudesmol, $\beta$-elemene, bicyclogermacrene, 10 -epi- $\gamma$-eudesmol, $\beta$ dihydroagarofuran and $\beta$-caryophyllene. Moreover, this is the first report of the occurrence of the sesquiterpene premnaspirodiene in the essential oil from a species of the genus Piper. In contrast, the other major constituents identified in the present study have also been reported for other species of Piper collected in different regions of Brazil and the world. For instance, the percentage of linalool in found in the oil from $P$. alatipetiolatum (43.88\%) was greater than that reported for leaf oils from $P$. aduncum (31.7\%) collected in the state of São Paulo, Brazil [18], P. jacquemontianum (14.5\%) collected in the Republic of Panama [13] and P. augustum (10.3\%) collected in Costa Rica [19]. In contrast, this oxygenated monoterpene has been found at higher percentages in the oil from $P$. 
claussenianum (53.5\%) collected in the state of Espírito Santo, Brazil [20] and P. jacquemontianum $(69.4 \%)$ collected in Guatemala [21].

Caryophyllene oxide was characterized as the major constituent of the oil from P. curtistilum (28.69\%) and has been found in lower quantities in the leaf oil from other species of Piper, such as $P$. amapense (17.0\%) and $P$. duckei (18.4\%) collected in the state of Amazonas, Brazil [22], $P$. carniconnectivum (21.3\%) in the state of Rondonia, Brazil [23], P. miniatum (20.3\%) in Malaysia [24] and $P$. brachypodom (10.8\%) in Colombia [25].

$\alpha$-Eudesmol was the main component in the oils from $P$. japurense $(22.05 \%)$ and $P$. coariense (27.33\%) and has been found at lower percentages in P. duckei $(9.1 \%)$ and P. arboreum $(12.21 \%)$ in the Brazilian states of Amazonas and Rio de Janeiro, respectively [22, 26].

In the present investigation, $\beta$-elemene was found in a significant quantity in the oil from $P$. brevesanum $(12.75 \%)$. This compound has been identified at higher percentages in the leaf oil from $P$. demerararum (33.1\%) in the state of Amazonas, Brazil [27] and P. reticulatum (16.1\%) in the Republic of Panama [13].

Bicyclogermacrene was found in the oils from $P$. japurense $(1.38 \%)$ and was a major component of the oil from $P$. brevesanum (11.61\%). This sesquiterpene has also been found at higher percentages in oils from $P$. arboreum (21.40\%) and P. amalago (16.4\%) collected from the Brazilian states of Rondônia [7] and Minas Gerais [28], respectively.

10-epi- $\gamma$-Eudesmol (13.32\%) and $\beta$-dihydro agarofuran (15.35\%) were major constituents of the oil from $P$. coariense and have also been reported as major components of oils from other species of Piper that occur in different regions of Brazil. Previous studies report percentages of 10-epi- $\gamma$ eudesmol close to that found in the present study in the leaf oil from P. cernuum (16.8\%) collected in the state of Minas Gerais [28] and P. arboreum (11.6\%) collected in the Federal District of the country [29]. In contrast, $\beta$-dihydro agarofuran was identified in higher quantities than that reported herein in two samples of P. cernuum collected in the states of Santa Catarina (36.7\%) [30] and Minas Gerais $(22.4 \%)$ [28].

$\beta$-Caryophyllene was found in significant quantities in the leaf oils from $P$. coariense $(10.30 \%)$ and $P$. alatipetiolatum $(16.11 \%)$ and has been reported as a major constituent in the oil from other species of Piper in different regions of Brazil and the world. Similar quantities to that found in the oil from $P$. alatipetiolatum have been reported for leaf oils from $P$. diospyrifolium (16.76\%) and $P$. gaudichaudianum (17.4\%) collected in southern Brazil [31, 32]. Oliveira et al., (2016) found a similar percentage to that reported here for $P$. coariense in the oil from $P$. ilheusense $(11.8 \%)$, which occurs in the northeastern region of the country [4]. Similar percentages of $\beta$-caryophyllene are reported for $P$. pseudolanceifolium (11.6\%) collected in Colombia [33] and P. officinarum (11.2\%) collected in Malaysia [34]. Higher percentages (> 20\%) of $\beta$-caryophyllene have been reported in the leaf oil of other species of Piper in different locations, such as P. duckei (27.1\%) and P. cyrtopodon (34.6\%) in northern Brazil [27,35], P. dilatatum (25.03\%) in northeastern Brazil [36] as well as $P$. arboreum (25.1\%) and P. truncatum (24.2\%) in southeastern Brazil [18,37]. Outside Brazil, this sesquiterpene is reported as a major constituent of oils from $P$. majusculum (20.7\%) collected in Vietnam [38], $P$. longispicum (45.2\%) in the Republic of Panama [7], P. umbellatum (28.2\%) in Cameroon [39] and $P$. chaba $(28.6 \%)$ in India [14].

Other compounds belonging to the chemical classes of monoterpenes ( $\beta$-pinene, 1,8-cineole and limonene) and phenylpropanoids (safrole, apiole and dillapiole) have been reported in oils from other species of Piper that occur in Brazil and specifically in the state of Amazonas, but were not found in the present analyses $[6,7,16,18,40-42]$.

As a conlusion, this study offers the first description of the chemical profile of the essential oils from the leaves of the species $P$. japurense, $P$. coariense, $P$. auriculifolium, $P$. curtistilum, $P$. alatipetiolatum and P. brevesanum, which occur in the Amazonia Biome in northern Brazil. With the exception of $P$. alatipetiolatum, the oils from the other plants exhibited a predominance of sesquiterpenes. However, qualitative and quantitative differences were found in the chemical composition of the six species. Among the 108 constituents identified in the oils, premnaspirodiene (32.26\%), which was the major constituent of the leaf oil from P. auriculifolium, is reported for the first time for the genus Piper. 


\section{Acknowledgments}

The authors are grateful to the Fundação de Amparo à Ciência e Tecnologia do Estado de Pernambuco (FACEPE), Conselho Nacional de Desenvolvimento Científico e Tecnológico (CNPq) and Coordenação de Aperfeiçoamento de Pessoal de Nível Superior for awarding a grant (CAPES Proc. \# IBPG-0984-5.01/10; a productivity scholarship (CNPq, \# 312277/2013-0) and research funding for this study (CNPq \# 403162/203-0; FACEPE \# APQ-1008-1.06/15; APQ-0476-1.06/14; APQ-08601.06/16; IBPG-0715-1.06/18; BCT-0185-1.06/17).

\section{Supporting Information}

Supporting information accompanies this paper on http://www.acgpubs.org/journal/records-ofnatural-products

\section{ORCID 웅}

Carolina Alves de Araujo: 0000-0002-4293-1255

Claudio Augusto Gomes da Camara: 0000-0001-8508-1230

Marcílio Martins de Moraes: 0000-0002-7597-6775

Geraldo José Nascimento de Vasconcelos: 0000-0002-2581-9931

Marta Regina Pereira: 0000-0001-7236-2383

Charles Eugene Zartman: 0000-0001-8481-9782

\section{References}

[1] D.G. Frodin (2004). History and concepts of big plant genera, Taxon. 53, 753-776.

[2] Piperaceae. In: Lista de espécies da flora do Brasil. Jardim Botânico do Rio de Janeiro. (2017). Available from: http://floradobrasil.jbrj.gov.br/jabot/floradobrasil/FB12735

[3] M. Pio-Corrêa (1984). Dicionário de plantas úteis do Brasil e das exóticas cultivadas. Imprensa Nacional. Rio de Janeiro.

[4] R.A. Oliveira, A.M.A.D. Assis, L.A.M. Silva, J.L. Andrioli and F.F. Oliveira (2016). Chemical profile and antimicrobial activity of essential oil of Piper ilheusense, Chem. Nat. Compd. 52, 331-333.

[5] V. Woguem, F. Maggi, H.P. Fogang, L.A. Tapondjoua, H.M. Womeni, Q. Luana, M. Bramuccici, L.A. Vitali, D. Petrelli, G. Lupidi, F. Papa, S. Vittori and L. Barboni (2013). Antioxidant, antiproliferative and antimicrobial activities of the volatile oil from the wild pepper Piper capense used in Cameroon as a culinary spice, Nat. Prod. Commun. 8, 1791-1796.

[6] M.J.C. Araújo, C.A.G. Da Camara, F.S. Born, M.M. Moraes and C. A. Badji (2012). Acaricidal activity and repellency of essential oil from Piper aduncum and its components against Tetranychus urticae, Exp. Appl. Acarol. 57, 139-155.

[7] H.T. Santana, F.T.T. Trindade, R.G. Stabeli, A.A.E. Silva, J.S.L.T. Militão and V.A. Facundo (2015). Essential oils of leaves of Piper species display larvicidal activity against the dengue vector, Aedes aegypti (Diptera: Culicidae), Rev. Bras. Pl. Med. 17, 105-111.

[8] J.G.S. Maia and E.H.A. Andrade (2009). Database of the Amazon aromatic plants and their essential oils, Quím. Nova. 32, 595-622.

[9] H. Van Den Dool and P.D. Kratz (1963). A generalization of the retention index system including linear temperature programmed gas-liquid partition chromatography, J. Chromatogr. A. 11, 463-471.

[10] R.P. Adams (2007). Identification of Essential Oil Components by Gas Chromatography/Quadrupole Mass Espectroscopy, 4th ed. Allured publishing Co. Carol Stream, Illinois.

[11] P.J. Linstrom and W.G. Mallard (2014). NIST Chemistry WebBook, NIST Standard Reference Database Number 69. (http://webbook.nist.gov).

[12] V.I. Babushok, P.J. Linstrom and I.G. Zenkevich (2011). Retention indices for frequently reported compounds of plant essential oils, J Phys Chem Ref Data. 40, 1-47.

[13] A.I. Santana, R. Vila, S. Cañigueral and M.P. Gupta (2016). Chemical composition and biological activity of essential oils from different species of Piper from Panama, Planta Med. 82, 986-991.

[14] K.B. Rameshkumar, A.P. Anu Aravind and P.J. Mathew (2011). Comparative phytochemical evaluation and antioxidant assay of Piper longum L. and Piper chaba Hunter used in Indian traditional systems of medicine, J. Herbs Spices Med. Plants. 17, 351-360. 
[15] E.H.A. Andrade and M.G.B. Zoghbi (2007). Volatile constituents of the leaves and stems of Piper glandulosissimum Yunck, J. Essent. Oil Res. 19, 401-402.

[16] F.V. Pacheco, R.P. Avelar, I.C.A. Alvarenga, S.K.V. Bertolucci, A.A. Alvarenga and J.E.B.P. Pinto (2016). Essential oil of monkey-pepper (Piper aduncum L.) cultivated under different light environments, Ind. Crop. Prod. 85, 251-257.

[17] R.Takeara, R. Gonçalves, V.F.S. Ayres and A.C. Guimarães (2017). Biological properties of essential oils from the Piper species of Brazil: A review. In: Aromatic and Medicinal Plants-Back to Nature. Ed: InTechOpen, Croatia, pp. 81-93.

[18] H.M.D. Navickiene, A.A. Morandim, A.C. Alécio, L.O. Regasini, D.C.B. Bergamo, M. Telascrea, A.J. Cavalheiro, M.N. Lopes, V.S. Bolzani, M. Furlan, M.O.M. Marques, M.C.M. Young and M.J. Kato (2006). Composition and antifungal activity of essential oils from Piper aduncum, Piper arboreum and Piper tuberculatum, Quím. Nova. 29, 467-470.

[19] J.F. Cicció (2005) Essential oil from the leaves of Piper augustum from "Alberto M. Brenes" biological preserve, Costa Rica, J. Essent. Oil Res. 17, 251-253.

[20] A.M. Marques, C.E. Fingolo and M.A.C. Kaplan (2017). HSCCC separation and enantiomeric distribution of key volatile constituents of Piper claussenianum (Miq.) C. DC. (Piperaceae), Food Chem Toxicol. 109, 1111-1117.

[21] S.M. Cruz, A. Cáceres, L. Álvarez, J. Morales, M.A. Apel, A.T. Henriques, E. Salamanca, A. Giménez, Y. Vásquez and M.P. Gupta (2011). Chemical composition of essential oils of Piper jacquemontianum and Piper variabile from Guatemala and bioactivity of the dichloromethane and methanol extracts, Rev. Bras. Farmacogn. 21, 587-593.

[22] A.S. Santos, E.H.A. Andrade, M.D.G.A. B. Zoghbi, A.I.R. Luz and J.G.S. Maia (1998). Sesquiterpenes of Amazonian Piper species, Acta Amaz. 28, 127-127.

[23] V.A. Facundo, C.M. Rezende, A.C. Pinto (2006). Essential oil of Piper carniconnectivum C.CD. Leaves and Stems, J. Essent. Oil Res. 18 296-297.

[24] W.M. Salleh, M.F. Kammil, F. Ahmad and H.M. Sirat (2015). Antioxidant and anti-inflammatory activities of essential oil and extracts of Piper miniatumi, Nat. Prod. Commun. 10, 2005-2008.

[25] S.M. Leal, N. Pino, E.E. Stashenko, J.R. Martínez and P. Escobar (2013). Antiprotozoal activity of essential oils derived from Piper spp. grown in Colombia, J. Essent. Oil Res. 25, 512-519.

[26] P.R.D. Santos, D.L. Moreira, E.F. Guimarães and M.A.C. Kaplan (2001). Essential oil analysis of 10 Piperaceae species from the Brazilian Atlantic forest, Phytochemistry 58, 547-551.

[27] D.F.M. Carmo, A.C.F. Amaral, G.M.C. Machado, L.L. Leon and J.R.A. Silva (2012). Chemical and biological analyses of the essential oils and main constituents of Piper species, Molecules 17, 18191829.

[28] J.M.O. Mesquita, C. Cavaleiro, A.P. Cunha, J.A. Lombardi and A.B. Oliveira (2005). Estudo comparativo dos óleos voláteis de algumas espécies de Piperaceae, Rev. Bras. Farmacogn. 15, 6-12.

[29] M.C.L. Potzernheim, H.R. Bizzo and R.F. Vieira (2006). Análise dos óleos essenciais de três espécies de Piper coletadas na região do Distrito Federal (Cerrado) e comparação com óleos de plantas procedentes da região de Paraty, RJ (Mata Atlântica), Rev. Bras. Farmacogn. 16, 246-251.

[30] A. Gasparetto, A.B. Cruz, T.M. Wagner, T.J. Bonomini, R. Correa and A. Malheiros (2017). Seasonal variation in the chemical composition, antimicrobial and mutagenic potential of essential oils from Piper cernuum, Ind. Crop. Prod. 95, 256-263.

[31] S.C.H. Vieira, L.F. Paulo, T.I.E. Svidzinski, B.P.D. Filho, C.V. Nakamura, A. Souza, M.C.M. Young and D.A.G. Cortez (2011). Antifungal activity of Piper diospyrifolium Kunth (Piperaceae) essential oil, Braz. J. Microbiol. 42, 1001-1006.

[32] G.L. von Poser, L.R. Rörig, A.T. Henriques, G. Lamaty, C. Menut and J.M. Bessière (1994). Aromatic plants from Brazil. III. The chemical composition of Piper gaudichaudianum Kunth and P. mikanianum (Kunth) Steudel essential oils, J. Essent. Oil Res. 6, 337-340.

[33] K. Caballero-Gallardo, N. Pino-Benitez, N. Pajaro-Castro, E. Stashenko and J. Olivero-Verbel (2014). Plants cultivated in Choco, Colombia, as source of repellents against Tribolium castaneum (Herbst), $J$. Asia-Pac. Entomol. 17, 753-759.

[34] W.M.N.H.W. Salleh, F. Ahmad, H.M. Sirat and K.H. Yen (2012). Chemical compositions, antioxidant and antimicrobial activity of the essential oils of Piper officinarum (Piperaceae), Nat. Prod. Commun. 7, 1659-1662.

[35] E.H.A Andrade, E.F. Guimarães, M.H.L. Silva and R.A. Pereira (2006). Essential oil composition of Piper cyrtopodon (Miq.) C. DC., J. Essent. Oil. Bear. Plant. 9, 53-59.

[36] J.B. Cysne, K.M. Canuto, O.D.L. Pessoa, E.P. Nunes and E.R. Silveira (2005). Leaf essential oils of four Piper species from the State of Ceará - Northeast of Brazil, J. Brazil. Chem. Soc. 16, 1378-1381.

[37] A.P.F. Trindade, L.S.M. Velozo, E.F. Guimarães and M.A.C. Kaplan (2010). Essential oil from organs of Piper truncatum Vell, J. essent. oil Res. 22, 200-202. 
[38] L.D. Hieu, T.D. Thang, T.M. Hoi and I.A. Ogunwande (2014). Chemical composition of essential oils from four Vietnamese species of Piper (Piperaceae), J. Oleo Sci. 63, 211-217.

[39] T. Francois, J.D.P. Michel, S.M. Lambert, F. Ndifor, W.N.A. Vyry, A.Z.P. Henri and M. Chantal (2009). Comparative essential oils composition and insecticidal effect of different tissues of Piper capense L., Piper guineense Schum. et Thonn., Piper nigrum L. and Piper umbellatum L. grown in Cameroon, Afr. J. Biotechnol. 8, 424-431.

[40] J.K. Silva, R. Trindade, N.S. Alves, P.L. Figueiredo, J.G.S. Maia and W.N. Setzer (2017). Essential oils from neotropical Piper species and their biological activities, Int. J. Mol. Sci. 18, 1-42.

[41] R.N.P Souto, A. Y. Harada , E. H. A. Andrade and J. G. S. Maia (2012). Insecticidal activity of Piper essential oils from the Amazon against the fire ant Solenopsis saevissima (Smith) (Hymenoptera: Formicidae), Neotrop. Entomol. 41, 510-517.

[42] A.I.R. Luz, J. D. da Silva, M.G.B. Zoghbi, E.H.A. Andrade, M.H.L. da Silva and J.G.S. Maia (2000). Volatile constituents of Brazilian Piperaceae. Part 4. Essential oil composition of Piper dactylostigmum, P. plurinervosum and P. Vitaceum, J. Essent. Oil Res. 12, 94-96.

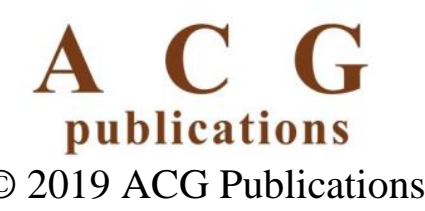

